Pobrane z czasopisma Wschód Europy http://journals.umcs.pl/we Data: 26/04/2023 13:40:35

D0l:10.17951/we.2020.6.1.13-29 $\quad$ Wschód Europy • Восток Европы • East of Europe vol 6, 1 / 2020

Роман Мартынюк

ORCID ID: https://orcid.org/0000-0003-4469-7762

Национальный университет "Острожская академия", Украина

\title{
Президент и исполнительная власть: анализ моделей соотношения институтов
}

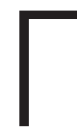

лавный вопрос в дискуссии о соотношении президента с исполнительной властью состоит в том, может ли президент сочетать функции главы государства с функциями главы исполнительной власти, и каковы последствия такого сочетания? Неоправданное ограничение влияния президента на исполнительную власть искажает его функциональную природу. В то же время, чрезмерное влияние президента на исполнительную власть неизбежно порождает авторитарные тенденции в функционировании государственного механизма. Это актуализирует поиск оптимальной модели соотношения президента с исполнительной властью.

Статус главы государства и правительства наиболее четко отражает отличия форм правления. Способ соотношения президента с исполнительной властью - один из важных классифицирующих элементов формы правления, во многом определяющий ее сущность. Каждая форма правления устанавливает присущий ей способ соотношения главы государства с исполнительной властью и указывает на степень сочетания этих институтов ${ }^{1}$. Если в классической президентской республике президент является главой исполнительной власти, то в парламентарной республике он максимально дистанцирован от нее. В смешанной республике президент, учитывая его статус координатора-арбитра, структурно выведен за пределы исполнительной власти, однако существенно интегрирован в нее функционально. Все же, несмотря на указанные различия, само явление сочетания президента с исполнительной властью характеризует все современные республиканские формы правления ${ }^{2}$.

В. Шаповал, Виконавча влада (теоретичний і конституційний аспекти), Київ 2018, с. 7.

2 Idem, Виконавча влада в Україні у контексті форми державного правління (досвід до прийняття Конституції України 1996 року), „Право України” 2016, № 3, с. 74. 
Организация государственной власти в президентской, парламентарной и смешанной республиках воплощает альтернативные доктринальные подходы к определению функциональной природы президента и, в частности, к вопросу о его соотношении с исполнительной властью. Глава государства владел исполнительной властью еще с тех времен, когда разделение властей только начало осуществляться. Это объясняет, почему всегда определенную часть полномочий президента по их содержанию можно отождествить или ассоциировать с исполнительной властью. В то же время, способ компетенционного и функционального сочетания президента с исполнительной властью в республиканских формах правления обнаруживает существенные и принципиальные различия 3 . Это усложняет теоретическое решение вопроса о месте и роли президента в структуре государственного механизма.

История развития республиканской формы правления обозначена поиском оптимального структурного и функционального соотношения президента с исполнительной властью. Результаты этого поиска в определяющей степени обусловили отличия конституционно-правового статуса президента в современных республиках.

До появления во Франции в 1958 г. «полноценной» смешанной республики существовали две традиционные модели соотношения президента с исполнительной властью, которые отражены в теории и практике классических - президентской и парламентарной республиканских форм правления. Президентскую и парламентарную республики характеризуют два альтернативных и, в сущности, «полярных» подхода к вопросу о соотношении президента с исполнительной властью: в первом случае (президентская республика) президент возглавляет ее, во втором случае (парламентарная республика) президент максимально от нее дистанцирован.

В смешанной республике президент, учитывая его статус координатора-арбитра, структурно выведен за пределы исполнительной власти, однако существенно интегрирован в нее функционально.

Исторически сложившаяся компетенция главы государства охватывала, прежде всего, такие сферы его деятельности, как представительство государства в целом, руководство вооруженными силами и системой исполнительной власти. Однако в процессе становления и развития современного демократического государства произошло существенное функциональное и структурное дистанцирование его главы - как монарха, так и президента - от исполнительной власти. Упомянутая тенденция в развитии института главы государства наиболее отчетливо прослеживается в странах с парламентарной формой правления. Совершенно особое соотношение президента с исполнительной властью характеризует смешанную республиканскую форму правления. И только в президентской республике президента можно отождествить с исполнительной властью.

3 В. Чиркин, Глава государства. Сравнительно-правовое исследование, Москва 2010, с. 82. 
Pobrane z czasopisma Wschód Europy http://journals.umcs.pl/we

Data: 26/04/2023 13:40:35

Президент и исполнительная власть: анализ моделей соотношения институтов

Анализ основных моделей соотношения президента с исполнительной властью в современных республиканских формах правления позволяет утверждать о принципиальном преимуществе смешанной республиканской формы правления над классическими республиками. Смешанная республика создает институциональные условия для оптимального соотношения президента с исполнительной властью. Присущая ей дуалистическая организация исполнительной власти, то есть ее разделение между президентом и правительством, обеспечивает паритет взаимовлияния этих субъектов. Взаимозависимость президента и премьер-министра в принятии соответствующих решений обеспечивает единство государственной политики, осуществляемой в сферах их совместной компетенции, минимизирует риск злоупотребления исполнительной властью. В то же время, достижение реального дуализма исполнительной власти, о чем свидетельствует, в частности, опыт постсоветских республик, очень сложно. Президенциализация или парламентаризация смешанной республики, то есть ее сближение с одним из ее материнских типов, искажает природу этой формы правления и «реставрирует» присущий классическим республикам способ соотношения президента с исполнительной властью.

\section{Генетическая связь главы государства с исполнительной властью и влияние института монарха на современный институт президента}

Президент - «исторический преемник» монарха в структуре государственного механизма ${ }^{4}$ и важно помнить, что в абсолютной монархии глава государства олицетворял государственную власть как таковую, и, прежде всего, исполнительную власть. Поэтому статус монарха определяли, в частности, как главы исполнительной власти. Функциональную сопряженность монарха с исполнительной властью отчетливо отражает организация государственной власти в дуалистической монархии - форме правления, переходной от монархии абсолютной к парламентарной. Конституции и некоторых современных парламентарных монархий (Бельгия, Люксембург, Нидерланды, Норвегия) сохраняют «рудиментарные» положения о монархе как главе исполнительной власти.

В процессе становления современной республиканской государственности характер власти монарха в существенной степени был перенесен на президента, для которого глава государства - монарх во многом послужил прототипом. Президент, заняв место, которое занимал монарх, одновременно «унаследовал» с некоторыми особенностями и многие его полномочия. «Монархическими» полномочиями следует считать, прежде всего, полномочия главы президентской республики в сфере организации и деятельности исполнительной власти.

Поскольку в монархической форме правления глава государства был единоличным органом, которому принадлежала вся полнота исполнительной власти, первично с монархом ассоциировался и сам термин «глава исполнительной

4 Idem, Публичная власть, Москва 2005, с. 91. 
власти». Позже глава президентской республики осуществлял те же полномочия относительно исполнительной власти, что и монарх. Поэтому с исполнительной властью стали отождествлять и президента, распространив на него и термин «глава исполнительной власти».

Итак, полномочия президента в сфере организации и деятельности исполнительной власти - наследственная черта института монарха, с которым современный институт президента связан генетически. Эта связь объясняет, почему в исторически первой современной республиканской форме правления - президентской республике - глава государства оказался и главой исполнительной власти.

Идея совмещения статусов главы государства и главы исполнительной власти в одном лице современной государственно-правовой теорией в целом воспринята негативно. Упомянутое совмещение статусов рассматривается как пережиток монархической организации государственной власти и как практика, которая показала свою ошибочность и пагубность для демократии. Именно в этом кроется причина постепенного исчезновения классических президентских республик. Разграничение полномочий главы государства и главы исполнительной власти и их осуществление разными должностными лицами - принципиальная черта современной республиканской организации государственной власти. Сочетание в одном должностном лице статусов главы государства и главы исполнительной власти порождает неразрешимую функциональную дилемму. «Это сочетание ролей, - отмечает американский политолог С. Хангтингтон, - есть наследие древней практики; институт президента был создан, как заявлял в 1787 г. Джефферсон, как выборная монархия. Этот институт по замыслу должен был воплотить в себе прерогативы британской Короны, и, соответственно, его политические формы во многом суть формы дворцовой политики» 5 .

По сути, характерное для классической президентской республики наделение президента всей полнотой исполнительной власти - непреодоленный пережиток монархизма. Естественно, что воспроизведение этого регрессивного и архаического атрибута монархической организации государственной власти в республиканской форме правления влечет те же последствия. Оценивая практику наделения главы государства полномочиями главы исполнительной власти, российский юрист В. Чиркин говорит: «...Объявление главы государства органом исполнительной власти было первичной неудачей концепции разделения властей. Этот институт никогда не был только исполнительным - ни юридически, ни фактически» ${ }^{6}$.

Ретроспективно в развитии института президента прослеживается тенденция его структурно-функционального дистанцирования от исполнительной власти. В то же время, поскольку генетическая связь этого института с испол-

\footnotetext{
С. Хангтингтон, Политический порядок в меняющихся обществах, Москва 2004, с. 127.
}

6 В. Чиркин, Глава государства. Сравнительно-правовое исследование, Москва 2010, с. 96. 
Pobrane z czasopisma Wschód Europy http://journals.umcs.pl/we

Data: 26/04/2023 13:40:35

Президент и исполнительная власть: анализ моделей соотношения институтов

нительной властью сохраняется при любой республиканской форме правления, сама его функциональная природа требует определенного включения в правительственную деятельность.

Разные взгляды на соотношение президента с исполнительной властью обусловили существенную вариативность республиканской формы правления. Они же свидетельствуют, что вопрос о функциональной природе президента и способе его сочетания с исполнительной властью на сегодня остается предметом научной дискуссии.

\section{Изъяны президенциализма}

В основе разных способов соотношения президента с исполнительной властью лежат противоположные доктринальные представления о его природе и роли в государственном механизме. В частности, присущий государствоведению Соединенных Штатов Америки подход предполагает сочетание функций главы государства и главы исполнительной власти. Согласно этому подходу, баланс властей предоставляет президенту полноту исполнительной власти.

В президентской республике президент как глава исполнительной власти соединен с ней и структурно, и функционально. Он обладает полнотой кадровых полномочий в исполнительной отрасли, и даже при наличии должности премьер-министра и скрепления со стороны последнего актов президента, здесь не возникает дуализма исполнительной власти. Интеграцию президента в исполнительную власть обосновывает идея «жесткого» разделения властей, которая требует структурного соединения всех органов государственной власти с одной из трех «разделенных властей». В условиях «жесткого» разделения властей правительства как независимого коллегиального органа исполнительной власти не существует, как не существует и должности премьер-министра, а все традиционные полномочия правительства находятся в компетенции президента. В президентской форме правления организация руководящего звена в системе органов исполнительной власти единоличная, а позиция его членов во время голосования имеет совещательный характер. Как реальный глава исполнительной власти, президент самостоятельно определяет правительственную политику, а легитимность администрации президента никак не связана с получением вотума доверия от парламента.

Учитывая то, что в президентской форме правления в статусе президента сочетаются функции главы государства и главы исполнительной власти, его природа здесь не определена. В этом прослеживается генетическая связь президентской республики с дуалистической монархией. По сути, в президентской республике единоличная организация руководящего звена в системе органов исполнительной власти является существенным рудиментом монархизма. Поскольку в президентской форме правления президент возглавляет исполнительную власть, ее политическая ответственность возможна только за результатами очередных президентских выборов. Даже когда политический курс президента теряет поддержку 
граждан, его невозможно легально сместить с должности, и ситуацию приходится терпеть, пока не закончится срок полномочий главы государства. Итак, президентская республика лишена конституционного механизма смещения непопулярного, а иногда и некомпетентного главы исполнительной власти. Очевидно и то, что организация государственной власти в президентской республике делает характер правления слишком зависимым от личных качеств президента. При таких условиях только высокий уровень развития гражданского общества может предотвратить трансформацию власти президента в единоличную диктатуру.

\section{Дефекты парламентаризма}

В парламентарной республике, о чем свидетельствуют конституции стран с этой формой правления, президент минимально соединен с исполнительной властью. Здесь его дистанцирование от исполнительной власти наиболее существенно. Он не соединен с ней ни структурно, ни с точки зрения его компетенции.

Хотя в странах с парламентарно-республиканской формой правления степень сочетания президента с исполнительной властью обнаруживает заметные формально-правовые различия, они не имеют принципиального значения. В парламентарной республике взаимодействие президента и правительства опосредовано институтом контрасигнатуры, в контексте применения которого и должны анализироваться компетенционные взаимосвязи этих субъектов. Контрасигнатура - скрепление определенных актов президента подписями премьер-министра и (или) профильного министра как условие вступления этих актов в силу. Отличительная черта парламентарной республики - распространение контрасигнатуры на все или почти все акты президента. Это обстоятельство обуславливает полную «связанность» его действий политической волей премьер-министра. Поэтому в парламентарной республике президент не может самостоятельно осуществлять свою конституционную компетенцию.

Крайнее ослабление влияния президента на исполнительную власть влечет определенные негативные последствия. Поэтому реализацию идеи дистанцирования президента от исполнительной власти в парламентарной республике сложно считать удачной. По сути, наделение премьер-министра всей полнотой исполнительной власти в парламентарной республике подменяет опасность единоличной президентской диктатуры опасностью диктатуры узко коллегиальной. Оценивая опасность для демократии, которую создает парламентарная форма правления, американский юрист и политолог Д. Горовиц отмечает: «Разумеется, возможно, что парламентские системы способствовали удушению демократии в Африке точно так же, как президентские системы способствовали этому в Латинской Америке ... злоупотребление властью вряд ли является президентской монополией. Парламентские режимы в странах Азии и Африки предоставили более чем изрядную долю случаев злоупотребления властью».

\footnotetext{
Д. Горовиц, Различия демократий, http://old.russ.ru, дата обращения: 08. 01. 2018.
} 
Pobrane z czasopisma Wschód Europy http://journals.umcs.pl/we

Data: 26/04/2023 13:40:35

Президент и исполнительная власть: анализ моделей соотношения институтов

В парламентарной республике угроза диктатуры в решающей степени обусловлена именно отсутствием «сильного», независимого в своих действиях и противопоставленного парламенту в смысле партийной принадлежности президента. В парламентарной форме правления потенциальный субъект этой диктатуры премьер-министр (он же - лидер парламентского большинства) и возглавляемое им правительство. Только пестрота партийных систем в европейских странах с парламентарной формой правления и порождаемая ею относительная правительственная нестабильность нивелируют потенциальные авторитарные тенденции классического парламентаризма.

\section{Преимущества разделенной исполнительной власти}

В отношении организации исполнительной власти смешанная республика обнаруживает принципиальное конститутивное преимущество над классическими типами республиканской формы правления. Характерная для нее модель соотношения президента с исполнительной властью обуславливает дуализм последней. Дуализм исполнительной власти делает невозможным ее сосредоточение в руках президента или премьер-министра. Характеризуя эту черту смешанной республики, американский политолог Дж. Сартори говорит: «... всякая полупрезидентская система должна некоторым образом устанавливать двоевластие между президентом, который является главой государства, и премьер-министром, который возглавляет правительство» ${ }^{8}$. Итак, в смешанной республике существенно ограничена возможность злоупотребления исполнительной властью как со стороны президента (недостаток президентской республики), так и премьер-министра (недостаток парламентарной республики).

Концепция смешанной республики рассматривает главу государства (президента) как функционально «нейтральный» элемент государственного механизма. Функционально «нейтральную» природу президента невозможно жестко привязать к любой из «разделенных властей». В смешанной республике президент структурно выведен за пределы исполнительной власти и, при этом, не образует отдельной отрасли власти. Он играет роль координатора-арбитра, обеспечивая согласованное взаимодействие высших органов государства. В этой форме правления координационно-арбитражная функция - «титульная» составляющая компетенции президента и, соответственно, образует основу его правового статуса. В то же время, президент - ключевой, наряду с органом конституционной юрисдикции, гарант конституционного строя. Отсюда другое важное направление его деятельности - обеспечение конституционных ценностей. Итак, в смешанной республике роль президента в государственном механизме связана, прежде всего, с его функциями гаранта и координатора-арбитра.

8 Дж. Сарторі, Порівняльна конституиійна інженерія: Дослідження структур, мотивів і результатів, Київ 2001, с. 115. 
Статус координатора-арбитра делает невозможной структурную или даже такую функциональную интеграцию президента в любую отрасль власти, которая могла бы повлечь в соответствующей отрасли его доминантную роль. Статус координатора-арбитра, в частности, не допускает отождествления президента с исполнительной властью. Это противоречило бы его посреднической роли в конфликтах между высшими органами государства и препятствовало бы реализации принципа разделения властей. Президент может возглавлять исполнительную власть или быть арбитром в системе разделения властей, но не может совмещать обе роли. Поэтому даже присущий смешанной республике дуализм исполнительной власти не дает оснований отождествлять с ней президента. Дуалистическая организация исполнительной власти не наделяет президента административными полномочиями по отношению к системе ее органов. Полнота этих полномочий принадлежит премьер-министру. В смешанной республике соотношение президента с исполнительной властью не может приводить к установлению административной зависимости руководителей ее органов от главы государства. Это устранило бы дуализм исполнительной власти, соответственно, исказило бы природу смешанной республики.

Присущий смешанной республике дуализм исполнительной власти предполагает наличие двух руководящих центров в сфере ее деятельности - премьер-министра и главы государства, соединенных между собой не структурно, а функционально. Соотношение этих субъектов с исполнительной властью не одинаково: если правительство является ее высшим руководящим органом, то президент соединен с исполнительной властью функционально - через определенный объем своих исполнительных полномочий. Такие полномочия, хотя и принадлежат президенту, являются исполнительными по своему характеру (юридической природе). При этом, несмотря на реальное и непосредственное функциональное сочетание президента с исполнительной властью, в смешанной республике парламентская ответственность правительства не приводит к досрочному прекращению полномочий президента. Это свидетельствует о том, что в смешанной республике президент не является руководителем исполнительной власти ${ }^{9}$. Дуализм исполнительной власти не означает, что ее разные сегменты подчиняются разным центрам - президенту или правительству, и конституционно определенным высшим органом исполнительной власти является правительство. В смешанной республике президента, учитывая характер его компетенции, невозможно отождествить ни с одной отраслью власти, и исполнительной в частности.

Общий для смешанных республик подход к распределению полномочий между президентом и премьер-министром в исполнительной отрасли заключается в том, что хотя соответствующие полномочия этих субъектов “переплетаются”, полномочия президента имеют определяющий характер. Глава государ-

9 Ф. Ардан, Франция: государственная система, Москва 1994, с. 73. 
Pobrane z czasopisma Wschód Europy http://journals.umcs.pl/we

Data: 26/04/2023 13:40:35

Президент и исполнительная власть: анализ моделей соотношения институтов

ства - президент - отвечает в основном за решение стратегических вопросов, контролирует такие сферы государственно-властной деятельности, как внешняя политика, оборона, а премьер-министр решает тактические задачи и осуществляет оперативное, повседневное управление. В ряде случаев президент обладает правом прекращать полномочия правительства, правом председательствовать на его заседаниях, что позволяет президенту играть, фактически, руководящую роль в сферах, в которых реализуется его совместная с правительством компетенция. Таким образом, в смешанной республике президент оказывает существенное влияние на деятельность исполнительной власти.

Совместная компетенция президента и правительства отражает стремление как совместить в организации исполнительной власти лучшие черты президентской и парламентарной форм правления, так и избежать их недостатков. Положительные черты дуалистической организации исполнительной власти - высокая функциональная эффективность правительства, что в существенной степени является следствием влияния на его организацию и деятельность со стороны президента, а также наличие достаточно самостоятельного в своих решениях и действиях премьер-министра - ставленника парламентского большинства. Дуализм исполнительной власти обеспечивает единство государственной политики, осуществляемой двумя самостоятельными субъектами - президентом и правительством.

Дуалистическая организация исполнительной власти основывается на осознании общего недостатка президентской и парламентарной форм правления сосредоточения полноты исполнительной власти в руках одного субъекта - президента или, соответственно, премьер-министра. В смешанной республике этот дефект классических республик устраняет дуализм исполнительной власти. Наличие двух руководящих субъектов исполнительной власти - президента и премьер-министра, ни один из которых не имеет доминирующих полномочий, при любой их партийной принадлежности исключает концентрацию исполнительной власти в руках одного из них.

\section{Соотношение президента с исполнительной властью в постсоветских президенциализированых республиках}

Вопрос о месте и роли президента в структуре государственного механизма приобрел особое значение для многих постсоветских республик, которые столкнулись с необходимостью введения сильной власти президента при одновременном ограничении того риска, который она в себе таит ${ }^{10}$. Теоретические предпосылки решения этой дилеммы непосредственно связаны с определением функциональной природы президента и его оптимального соотношения с исполнительной властью.

10 А. Арутюнян, Институт президента Республики Армения (Сравнительно-правовой анализ), Ереван 1996, с. 65. 
В постсоветских президенциализированых республиках соотношение президента с исполнительной властью в целом соответствует критериям президентской формы правления. В то же время, общая черта, присущая государствоведению посткоммунистических стран - отсутствие серьезного концептуального обоснования института президента. Более того, на постсоветском пространстве в научной среде прослеживаются отдельные попытки обосновать и оправдать доминирующее положение президента в государственном механизме, в частности, и относительно исполнительной власти. Как следствие, в теории государствоведческих наук и реальной государственной практике стран, образовавшихся на территории бывшего Советского Союза, прослеживается неопределенность во взглядах на функциональную природу президента.

Завышенная оценка роли президента в государственном механизме обусловлена определенными негативными чертами большинства постсоветских политических систем. Все республики, возникшие на руинах Советского Союза, столкнулись с необходимостью получения реального суверенитета и независимости, укрепления государственности, гарантирования национальной безопасности, создания эффективной национальной экономики, обеспечения социально-политической стабильности, социального и культурного развития населения, интеграции в мировое сообщество или получения международного признания как его полноправного члена. Решение этих задач требовало концентрированной политической воли, опертой на организованную исполнительную власть. Олицетворением этой воли стал президент. Концентрацию власти в его руках усиливало частое появление кризисных ситуаций в сфере внутренней и внешней политики, преодоление которых требовало немедленных и решительных действий с применением всей полноты ресурсов государственной власти ${ }^{11}$. Успешное решение серьезных социально-экономических и политических проблем диктовало наличие государственного механизма, способного обеспечить четкую и динамичную координацию действий всех его элементов. Поэтому концентрация власти в руках президента имела и вполне положительный эффект, играя роль интегративного фактора государственно-политической и социально-экономической жизни страны и тем самым усиливая стабильность и легитимность политической системы в целом ${ }^{12}$. Упомянутые обстоятельства во многом объясняют, почему на постсоветском пространстве президент довлеет над исполнительной властью.

Были и другие причины, способствовавшие концентрации исполнительной власти в руках президента. К их числу следует отнести, прежде всего, неразвитость партийной системы, слабость парламентаризма и порождаемую ими

1 Е. Сейлеханов, Политическая система Республики Казахстан: опыт развития и перспективы, Алматы 2009, с. 91-92.

12 А. Арутюнян, Место президента в системе политико-правовых институтов постсоветских республик, „Jurisprudencija” 2005, T. 77 (69), с. 6. 
правительственную нестабильность. Во многих постсоветских республиках неразвитость партийной системы, которая пребывает здесь по сей день, по сути, в «эмбриональном» состоянии, обусловила неспособность парламента существенно влиять на исполнительную власть. Хроническая неспособность парламента сформировать стабильное правительство привела к возникновению формы правления, в которой гарантом эффективности исполнительной власти стал президент. «Можно с уверенностью предсказать, - указывает американский юрист С. Холмс, - что сильная президентская власть появится там, где общество не столь организовано, чтобы избрать парламент, достаточно монолитный для создания и поддержки согласованного, способного на жесткие меры правительства» ${ }^{13}$. Стремление обеспечить правительственную стабильность объясняет, почему во многих государствах, возникших после распада Советского Союза, центр политического тяготения был существенно смещен в направлении президенциализма. Однако намерение обеспечить эффективность исполнительной власти путем усиления влияния на нее со стороны президента во многих случаях было осуществлено крайне неосторожно. В большинстве постсоветских республик усиление статуса президента достигло критической степени и повлекло его очевидное доминирование в государственном механизме. Поэтому форма правления, установленная в ряде постсоветских республик, может быть определена смешанной республикой лишь с большой условностью. Устранение дуализма исполнительной власти в пользу президента уже не позволяет классифицировать форму правления смешанной республиканской. В постсоветских президенциализированых республиках административное подчинение исполнительной власти президенту позволяет ему усиливать собственную легитимность за счет успехов правительственной политики и одновременно - перемещать на правительство свою политическую ответственность. Другим важным негативным последствием чрезмерного усиления влияния президента на исполнительную власть стала его неспособность исполнять координационно-арбитражную функцию. Статус президента как координатора-арбитра не допускает его вмешательства в компетенцию других органов государственной власти, нарушение их самостоятельности или их функциональную подмену. Этот статус предполагает одинаковую требовательность, нейтральность и беспристрастность президента ко всем органам государственной власти и их должностным лицам. Способность президента играть две альтернативные и несовместимые роли координатора-арбитра и гаранта с одной стороны, и главы исполнительной власти - с другой, всегда мотивационно определяет выбор в пользу второго направления деятельности президента и препятствует реализации его статуса гаранта конституционных ценностей, координатора механизма взаимодействия

13 С. Холмс, Посткоммунистический институт президента, „Конституционное право: восточноевропейское обозрение” 1994, № 4-5, с. 54. 
отраслей власти и посредника в государственно-правовых конфликтах ${ }^{14}$. Именно так всегда решается президентом дилемма функционального выбора в постсоветских президенциализированых республиках. Здесь президент, приобретя характеристики главы исполнительной власти, оказался неспособным играть в государственном механизме роль координатора-арбитра.

На сегодняшний день в ряде постсоветских республик произошла трансформация формы правления в направлении парламентаризма. Эта тенденция заметно проявилась в Грузии, Кыргызстане и Украине, в меньшей степени - в Узбекистане. Кое-где устранение административной зависимости правительства от главы государства привело к появлению «полноценной» смешанной республики. Например, согласно первичной редакции Конституции Украины 1996 г., президент играл определяющую роль в процессе формирования правительства, владел ничем не ограниченным дискреционным правом прекращать полномочия как правительства в целом, так и его отдельных членов, безоговорочным правом отменять правительственные акты. Конституционный закон «О внесении изменений в Конституцию Украины» от 8 декабря 2004 г. существенно дистанцировал президента от исполнительной власти. Согласно действующей редакции Конституции Украины, роль главы государства в процессе формирования правительства сведена к возможности представлять парламенту для утверждения кандидатуры премьер-министра, министра обороны и министра иностранных дел. При этом представление кандидатуры премьер-министра президент осуществляет по предложению парламентского большинства. Конституционные изменения лишили президента права прекращать полномочия правительства в целом и его отдельных членов, права отменять правительственные акты. Форма правления в Украине приобрела признаки парламентаризированой смешанной республики.

В ряде других постсоветских республик - Азербайджане, Беларуси, Казахстане, Российской Федерации, Таджикистане, Туркменистане, Узбекистане президент, как и прежде, остается фактическим главой исполнительной власти. В Беларуси, например, президент играет решающую роль как в формировании состава правительства, а так и в организации его деятельности. Президент определяет структуру правительства, назначает с согласия нижней палаты парламента премьер-министра, назначает заместителей премьер-министра, министров и других членов правительства. Президент имеет право председательствовать на заседаниях правительства, дискреционно отменяет его акты, вправе по собственной инициативе принять решение об отставке правительства и освободить от должности любого его члена. Правительство слагает свои полномочия перед вновь избранным президентом. Примечательно, что в Основном Законе Беларуси правительство определено «центральным органом государственного управления», а не руководящим органом исполнительной власти.

14 М. Краснов, Персоналистский режим в России: опыт институционального анализа, Москва 2006, c. $169-170$. 
Анализируя форму сочетания президента Российской Федерации с исполнительной властью, российский юрист М. Баглай указывает: «Анализ полномочий Президента Российской Федерации и Правительства Российской Федерации дает все основания считать главой исполнительной власти Российской Федерации именно Президента Российской Федерации, а не Председателя Правительства или Правительство Российской Федерации в целом. Поэтому когда утверждают, что Правительство Российской Федерации является высшим органом исполнительной власти, то необходимо принимать во внимание известную условность такого утверждения» ${ }^{15}$.

Постсоветские президенциализированые республики характеризует отсутствие конституционных механизмов непосредственного участия политических партий в выработке и осуществлении правительственной политики. Эту политику формирует и осуществляет единственный субъект - президент. При недостаточном влиянии политических партий на государственный механизм не способно влиять на политику президента и парламентское большинство. Президент может осуществлять свою политику, вообще не обращая на него внимания ${ }^{16}$. Поэтому в постсоветских президенциализированых республиках именно президент является реальным руководителем системы органов исполнительной власти.

Нельзя обойти вниманием негативные последствия подчинения президенту исполнительной власти для перспектив политического развития постсоветских республик. Одним из очевидных последствий административной зависимости исполнительной власти от президента в условиях слабости демократических политических институтов стало развитие в постсоветских республиках явления сверхпрезидентства. Существует определенный предел, за которым роль президента в политической системе становится губительной для развития демократии. Вне сомнения, роль, которую играет президент в политической системе постсоветских президенциализированых республик, находится за этим пределом и вызывает вполне реальную угрозу скатывания страны к авторитаризму или даже тоталитаризму.

\section{Выводы}

Изложенное выше дает возможность сформулировать следующие выводы. Хотя президентская и парламентарная формы правления воплощают две альтернативные модели соотношения президента с исполнительной властью, их общий недостаток состоит в том, что обе они предусматривают сосредоточение исполнительной власти в руках одного властвующего субъекта - главы государства (президентская республика) или премьер-министра (парламентарная республи-

15 М. Баглай, Президенты Российской Федерации и Соединенных Штатов Америки. Роль, порядок выборов, полномочия, Москва 2008, с. 63-64.

16 С. Холмс, Сверхпрезидентство и его проблемыl. „Конституционное право: восточноевропейское обозрение" 1994, № 4-5, с. 23-24. 
Pobrane z czasopisma Wschód Europy http://journals.umcs.pl/we

Data: 26/04/2023 13:40:35

ка). Поэтому обе эти модели содержат авторитарный потенциал. Присущая смешанной республике модель соотношения президента с исполнительной властью имеет ряд преимуществ. Даже при одинаковой партийной «окраске» президента и премьер-министра разделенная исполнительная власть исключает концентрацию своей полноты в руках одного из них. В условиях дуализма исполнительной власти невозможно превращение правительства в фактическое дополнение аппарата президента. В то же время, существенная вовлеченность президента в организацию и деятельность правительства - важное условие его эффективности и стабильности.

Оптимальное соотношение президента с исполнительной властью практически воплощено в немногих случаях. Президенциализация и парламентаризация смешанной республики разрушают присущий ей дуализм исполнительной власти и воспроизводят тот способ соотношения президента с исполнительной властью, который характеризует президентскую и, соответственно, парламентарную республики. Только в сбалансировано-смешанной республике соотношение полномочий президента и премьер-министра гарантирует их паритетное влияние на исполнительную власть.

Концепция смешанной республики оказала существенное влияние на конструирование формы правления в большинстве постсоветских республик. Однако намерение обеспечить правительственную эффективность и стабильность посредством увеличения влияния на исполнительную власть со стороны президента повлекло чрезмерное усиление его статуса. Как следствие, в большинстве постсоветских республик не удалось избежать административного подчинения правительства президенту и дуализм исполнительной власти был устранен. Ее фактическим главой оказался президент. Это стало важной причиной сворачивания демократии и развития в постсоветских республиках явления свехпрезидентства.

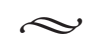

\section{Президент и исполнительная власть: анализ моделей соотношения институтов}

Аннотация: История развития республиканской формы правления обозначена постоянными поисками оптимального структурного и функционального соотношения президента с исполнительной властью. Глава государства сохранял за собой исполнительную власть еще с тех времен, когда разделение властей только начало осуществляться. Это объясняет, почему всегда определенную часть полномочий президента по их содержанию возможно отождествить или ассоциировать с исполнительной властью. В то же время, способ компетенционного и функционального сочетания президента с исполнительной властью в республиканских формах правления обнаруживает существенные и принципиальные различия. И на текущий момент вопрос 
Pobrane z czasopisma Wschód Europy http://journals.umcs.pl/we

Data: 26/04/2023 13:40:35

Президент и исполнительная власть: анализ моделей соотношения институтов

о соотношении президента с исполнительной властью остается предметом научной дискуссии. Если в президентской форме правления президент - глава исполнительной власти, то в парламентарной республике он максимально дистанцирован от нее. В смешанной республике президент занимает промежуточное положение между этими двумя "полярными" позициями. Здесь президент существенно интегрирован в исполнительную власть функционально, однако не является ее структурной составляющей. Анализ функциональных дефектов президентской и парламентарной республик позволяет сделать Вывод о том, что организация государственной власти в смешанной республиканской форме правления обеспечивает оптимальное соотношение президента с исполнительной властью. Преимущества смешанной республики над классическими республиками в упомянутом аспекте - ее способность обеспечить полноценную реализацию функционального потенциала института президента, совместить эффективность исполнительной власти с ее парламентской ответственностью, предотвратить возможность сосредоточения исполнительной власти в руках одного властвующего субъекта - президента или премьер-министра.

Ключевые слова: глава государства, президент, исполнительная власть, государственный механизм, форма правления

\section{Prezydent i władza wykonawcza: poszukiwanie optymalnego modelu relacji instytucji}

Streszczenie: Historia rozwoju republikańskiej formy rządów cechuje się nieustannymi poszukiwaniami optymalnej strukturalnej i funkcjonalnej relacji pomiędzy prezydentem a władzą wykonawczą. Głowa państwa zachowała przy sobie władzę wykonawczą jeszcze z czasów, kiedy dopiero zaczynało się rozdzielanie władzy. To tłumaczy fakt, dlaczego zawsze pewną część władzy prezydenta można identyfikować lub wiązać z władzą wykonawczą. Jednocześnie sposób kompetencjonalnego i funkcjonalnego połączenia władzy prezydenta z władzą wykonawczą w republikańskich formach rządów wykazuje istotne i zasadnicze różnice. Współcześnie pytanie o relacje prezydenta z władzą wykonawczą pozostaje przedmiotem dyskusji naukowej. Jeżeli w prezydenckiej formie rządów prezydent jest głową władzy wykonawczej, to w republice parlamentarnej jest on maksymalnie od niej zdystansowany. W mieszanej republice prezydent zajmuje pośrednie miejsce pomiędzy tymi dwiema skrajnymi pozycjami. W tej formie rządów prezydent jest istotnie zintegrowany funkcjonalnie z władzą wykonawczą, jednak nie jest jej jednostką strukturalną. Analiza wad funkcjonalnych prezydenckiej i parlamentarnej republikańskiej formy rządów zezwala na wyciągnięcie wniosku, iż organizacja władzy państwowej w mieszanej republikańskiej formie rządów zapewnia optymalną relację pomiędzy prezydentem i władzą wykonawczą. Korzyści republiki mieszanej w stosunku do klasycznych republik w wyżej wspomnianym aspekcie są następujące: jej zdolność zabezpieczania pełnoprawnej realizacji potencjału funkcjonalnego instytucji prezydenta, połączenie efektywności władzy wykonawczej z jej parlamentarną odpowiedzialnością, zapobieganie możliwości skupienia się władzy wykonawczej w rękach jednego podmiotu panującego - prezydenta lub premiera.

Słowa kluczowe: głowa państwa, prezydent, władza wykonawcza, mechanizm państwowy, forma rządów 


\title{
The President and the Executive Power: the Analysis of the Types of Correlation between the Institutions
}

\begin{abstract}
The history of the republican form of government is marked by the constant search for the ideal structural and functional correlation between the presidencies and the executive branch. The head of the state has wielded executive power since the beginnings of the separation of powers. This explains why some presidential authorities can be associated with or identified by the executive branch. At the same time, there are fundamental critical distinctions between the ways of jurisdictional and functional interrelationships between the presidency and the executive branch in the republican forms of government. This issue currently remains the matter of an academic discussion. The president is the head of the executive branch in the presidential form of government, whereas the head of the state does not have executive powers in parliamentary republics. In a semi-presidential republic, however, the position of the president is somewhere in between these two polar ones: the head of the state is functionally integrated into the executive branch but is not a part of it. The analysis of the functional weaknesses of the presidential and parliamentary republics leads to the conclusion that semipresidential republics ensure ideal interrelationship between the president and the executive power. As far as the above-mentioned aspect is concerned, semi-presidential republics have advantages over classical ones since they can ensure the realization of the president's full institutional potential, to combine the executive branch efficiency with its parliamentary responsibilities, and to prevent the possibility of concentrating all executive power in the hands of one subject be it a president or prime minister.
\end{abstract}

Keywords: the head of the state, president, executive power, state machinery, the form of government

\section{Источники и литература}

\section{Монографии}

Ardan F., Francija: gosudarstvennaja sistema, Moskva 1994.

Arutyunyan A., Institut prezidenta Respubliki Armeniya (Sravnitelno-pravovoy analiz), Erevan 1996.

Baglay M., Prezidentyi Rosiyskoy Federatsii i Soedinennyih Shtatov Ameriki. Rol, poryadok vyiborov, poInomochiya, Moskva 2008.

Chirkin V., Glava gosudarstva: Sravnitel'no-pravovoe issledovanie, Moskva 2010.

Chirkin V., Publichnaya vlast, Moskva 2005.

Hangtington S., Politicheskiy poryadok v menyayuschihsya obschestvah, Moskva 2004.

Krasnov M., Personalistskiy rezhim v Rossii: opyit institutsionalnogo analiza, Moskva 2006.

Sartori Dzh., Porivnjaljna konstytucijna inzhenerija: Doslidzhennja struktur, motyviv i rezuljtativ, Kyiv 2001. Seylehanov E., Politicheskaya sistema Respubliki Kazahstan: opyit razvitiya i perspektivyi, Almatyi 2009. Shapoval V., Vykonavcha vlada (teoretychnyi i konstytutsiinyi aspekty), Kyiv 2018.

\section{Научные статьи}

Arutyunyan A., Mesto prezidenta v sisteme politiko-pravovyih institutov postsovetskih respublik, "Jurisprudencija" 2005, T. 77 (69). 
Pobrane z czasopisma Wschód Europy http://journals.umcs.pl/we

Data: 26/04/2023 13:40:35

Holms S., Postkommunisticheskiy institut prezidenta, "Konstitutsionnoe pravo: vostochnoevropeyskoe obozrenie" 1994, № 4-5.

Holms S., Sverhprezidentstvo i ego problemyi. "Konstitutsionnoe pravo: vostochnoevropeyskoe obozrenie" 1994, № 4-5.

Shapoval V., Vykonavcha vlada v Ukraini u konteksti formy derzhavnoho pravlinnia (dosvid do pryiniattia Konstytutsii Ukrainy 1996 roku), "Pravo Ukrajiny" 2016, № 3.

\section{Интернет-источники}

Gorovits D., Razlichiya demokratiy, http://old.russ.ru. 